Sains Malaysiana 50(4)(2021): 889-896

http://ddoi.org/10.17576/jsm-2021-5004-01

\title{
Callus Induction and Regeneration from Germinating Mature Embryos of Wheat (Triticum aestivum L.)
}

(Induksi Kalus dan Penjanaan Semula daripada Percambahan Embrio Matang Gandum (Triticum aestivum L.))

\author{
SAMIH M. TAMIMI* \& HALIMA OTHMAN
}

\begin{abstract}
A high-performance protocol for callus induction was devised using germinating mature embryos of two local wheat (Triticum aestivum L.) landraces as explant. The results showed that callus development from germinating embryos was rapid starting one day after culture with an induction rate 20 to $25 \%$ higher than those of soaked embryos. In addition, the mean rate of growth of callus developed from germinating embryos was 60 to $70 \%$ higher than those cultured from soaked embryos. This study also demonstrated a higher frequency of green spots formation (48 to $56 \%$ ) on callus derived from germinating embryos compared to their soaked counterpart (24 to 28\%), suggesting a better differentiation potential of callus cultures derived from germinating embryo. These findings indicate that germinating mature embryo is more suitable explant for wheat callus induction and regeneration than the soaked mature embryo commonly employed for wheat callus culture.
\end{abstract}

Keywords: Callus culture; germination; mature embryo; Triticum aestivum; wheat

\section{ABSTRAK}

Protokol berprestasi tinggi untuk induksi kalus telah dilakukan dengan menggunakan embrio matang yang dicambah daripada dua kultur gandum tempatan (Triticum aestivum L.) sebagai eksplan. Hasil kajian menunjukkan bahawa perkembangan kalus daripada embrio tersebut bercambah dengan cepat bermula sehari selepas kultur dengan kadar induksi 20 hingga 25\% lebih tinggi daripada embrio yang direndam. Di samping itu, kadar pertumbuhan kalus yang berkembang daripada embrio bercambah adalah 60 hingga 70\% lebih tinggi daripada yang dibiakkan daripada embrio yang direndam. Kajian ini juga menunjukkan frekuensi pembentukan tompok hijau yang lebih banyak (48 hingga 56\%) pada kalus yang berasal daripada embrio bercambah dibandingkan dengan kaunterpart yang direndam (24 hingga 28\%) menunjukkan potensi pembezaan yang lebih baik daripada kultur kalus yang berasal daripada percambahan embrio. Penemuan ini menunjukkan bahawa percambahan embrio matang lebih sesuai untuk induksi kalus gandum dan pertumbuhan semula berbanding teknik embrio matang direndam yang biasa digunakan untuk kultur kalus gandum.

Kata kunci: Embrio matang; gandum; kultur kalus; percambahan; Triticum aestivum

\section{INTRODUCTION}

One of the important steps in the genetic engineering of cereals is the successful plant regeneration from callus culture (Mendoza \& Kaeppler 2002). In wheat (Triticum aestivum L.), immature embryos have been the most widely used explants to initiate callus cultures (Yang et al. 2015). However, the limited seasonal availability of immature embryos besides their restricted stage for culture (12-20 days post-anthesis) (Zale et al. 2004) limits their use (Repellin et al. 2001) and makes them inconvenient for in vitro culture. Mature embryos or tissues derived from them have been used as an effective alternative to immature embryos because of their year round availability, easy isolation (Chugh \& Khurana 2003; Ding et al. 2009; Patnaik et al. 2006) and genetic stability (Yu et al. 2008).

Despite the progress made on the in vitro culture of wheat using mature embryo explants, their poor callogenesis and low plant regeneration remains the major obstacle that makes them difficult to use in practice thus emphasizing the need for optimizing their culture protocol. In fact, there is a general agreement that transgenic studies in wheat are difficult due to the lack of suitable explants 
with high regeneration efficiency (Yu et al. 2008). Several factors have been evaluated in order to optimize the overall regeneration capacity of wheat cultivars. Some of these factors include genotype screening and genetic influence, inoculation method, explant treatment, pre-culture incubation time and conditions, different media with organic/inorganic additives, and varying phytohormone concentrations (Battal 2010; Coskun et al. 2013; Ding et al. 2009; Miroshnichenko et al. 2013; 2011; 2009; Moghaieb et al. 2010; Murín et al. 2012; Ozbay \& Özgen 2010; Parmar et al. 2012; Rashid et al. 2009; Ren et al. 2010; Tang et al. 2006; Yin et al. 2011; Yu et al. 2008). Nevertheless, no previous work was undertaken to evaluate the influence of enhancing the biochemical status of mature embryos prior to using as explants. Since mature differentiated tissues are generally more difficult to re-enter cell division and proliferation than the metabolically more active immature tissues, stimulating metabolic activity of mature wheat embryos may increase the efficiency of their culture. A simple approach, that could enhance the metabolic activity of mature embryos, can be achieved by germinating seeds for a specific period of time (Rajjou et al. 2012). Hence, the main objective of this study was to examine the reliability of using mature embryos during early stages of seed germination as an explant for the in vitro culture and regeneration of wheat.

\section{MATERIALS AND METHODS}

\section{PLANT MATERIAL}

Mature wheat (Triticum aestivum) seeds of two locally grown landraces 'Tafila and Ajloun' were surfacesterilized with $70 \%(\mathrm{v} / \mathrm{v})$ ethanol for $2 \mathrm{~min}$ and then rinsed with sterile distilled water. Seeds were then treated with $30 \%(\mathrm{v} / \mathrm{v})$ sodium hypochlorite solution containing two drops of Tween 20 for $30 \mathrm{~min}$, followed by three times of washing with sterile distilled water. Mature embryos were excised from the surface-sterilized seeds either after imbibition in sterile distilled water for $4 \mathrm{~h}$ or after growth for $18 \mathrm{~h}$ on petri dishes containing full-strength MS basal medium (Murashige \& Skoog 1962) with no plant growth regulators.

\section{CALLUS INDUCTION}

Excised embryos were placed scutella up on callus induction media. The medium used for callus induction contained MS salts (Murashige \& Skoog 1962), $20 \mathrm{gL}^{-1}$ sucrose, $1 \mathrm{mLL}^{-1} \mathrm{MS}$ vitamin, $0.5 \mathrm{gL}^{-1}$ glutamine, 0.1
$\mathrm{gL}^{-1}$ casein hydrolysate and $100 \mathrm{mggL}^{-1}$ ascorbic acid. To determine the best level of plant growth regulators for callus induction and growth, the culture medium was supplemented with two concentrations of 2,4-D (2,4-dichlorophenoxyacetic acid): $2 \mathrm{mgL}^{-1}$ (medium $\mathrm{H} 1$ ) and $4 \mathrm{mgL}^{-1}$ (medium $\mathrm{H} 2$ ) alone or in combination with two concentrations of dicamba (3,6-dichloro-2methoxybenzoic acid) at $3 \mathrm{mgL}^{-1}$ (medium $\mathrm{H} 3$ ) and 4 $\mathrm{mgL}^{-1}$ (medium $\mathrm{H} 4$ ). The $\mathrm{pH}$ of the medium was adjusted to 5.8 and gelled with $2 \mathrm{gL}^{-1}$ Gellan Gum (Gelrite, Sigma Aldrich). Five embryos were cultured per $90 \mathrm{~mm}$ Petri plate containing $20 \mathrm{~mL}$ medium, and all experiments were laid out in a completely randomized design with four replicates per treatment. The cultured plates were incubated in darkness at $26-27^{\circ} \mathrm{C}$ and checked daily for callus development. Data recorded were time of callus initiation (days taken for callus initiation), callus induction frequency estimated at 4 weeks after embryo culture ((number of embryos producing callus)/(total number of embryos cultured in Petri dishes) X 100), and callus growth rate (CGR, mmday ${ }^{-1}$ ) by the formulas (1) and (2) of Compton (1994):

CGR1 $=$ D-7/7, CGR2 $=$ D-14/7, CGR3 $=$ D-21/7, and CGR $4=\mathrm{D}-28 / 7$

$\mathrm{CGR}=(\mathrm{CGR} 1+\mathrm{CGR} 2+\mathrm{CGR} 3+\mathrm{CGR} 4) / 4$

where D-7, D-14, D-21, and D-28 were diameter of callus (mm) measured at days $7,14,21$, and 28, respectively, after culture. Means of each treatment were separated by Duncan's Multiple Range Test (DMRT) $(\mathrm{p}<0.05)$.

\section{PLANT REGENERATION}

Four to five weeks-old compact calluses from germinating and soaked embryos were used for regeneration induction. They were transferred to phytagel solidified MS media supplemented with $30 \mathrm{gL}^{-1}$ sucrose, $1 \mathrm{mLL}^{-1} \mathrm{MS}$ vitamin, $2 \mathrm{mgL}^{-1}$ benzyl adenine (BA), $0.5 \mathrm{gL}^{-1}$ glutamine, $0.1 \mathrm{gL}^{-1}$ casein hydrolysate, $100 \mathrm{mgL}^{-1}$ ascorbic acid, $2 \mathrm{mgL}^{-1} \mathrm{CuSO}_{4}$ and $10 \mathrm{mgL}^{-1} \mathrm{AgNO}_{3}$ (Kumar et al. 2017). Cultures were maintained at $25{ }^{\circ} \mathrm{C}$ under a $16-\mathrm{h}$ photoperiod for 4 weeks. The fraction of callus that formed green spots and the fraction of regenerating callus were noted for 28 days after regeneration induction. Percent callus forming green spots (differentiation rate) was used to estimate callus regeneration potential. Five replicates were employed per treatment, and petri dishes containing five calluses were considered as the units of replication. 


\section{RESULTS}

In this study, media supplemented with 2,4-D (H1 and $\mathrm{H} 2$ ) and combination of 2,4-D and dicamba (H3 and H4) were initially tested for callus induction from germinating and soaked embryos of the two local wheat landraces. Callus were formed from both landraces on all media employed within one to a few days, but the best response for callus growth was observed from embryos cultured on medium $\mathrm{H} 3$ containing $2 \mathrm{mgL}^{-1}$ 2,4-D and $3 \mathrm{mgL}^{-1}$ dicamba (Figure 1). Therefore, this medium was used for further experiments on callus induction.

Callus from germinating embryos of the two landraces started to develop at least 2 days earlier than those from soaked embryos. Visible callus tissue was consistently observed after one day and 3 to 5 days of inoculation for germinating and soaked embryos, respectively (Table 1). At the end of the callus induction period, the percentage callus formation, averaged over landraces from 96 to $100 \%$ in cultures of germinating embryos and from 72 to $76 \%$ in soaked embryo cultures (Table 1), suggesting a significant enhancement of callus induction capacity by the pre-germination treatment of mature wheat embryo explants.

The callus was also compared for their fresh weight and mean rate of growth during 28 days of culture. Considering overall averages of these parameters, callus formed from germinating embryos gave significantly higher callus weight and growth rate $(180$ and $200 \mathrm{mg}$; 1.32- and 1.4-mm day $\left.{ }^{-1}\right)$ compared to callus of soaked embryos ( 83 and $89 \mathrm{mg} ; 0.78$ - and $0.88-\mathrm{mm} \mathrm{day}^{-1}$ ) of Tafila and Ajloun landraces, respectively (Figures 1-3). These values showed that the germination treatment of embryos prior to callus induction almost doubled the growth rate of developing callus, and this stresses the favorable potential of this treatment for improving the efficiency of callus induction and growth from mature wheat embryos.

The results of this study also showed that the regeneration potentials of callus cultures from germinating embryos were higher than those from soaked embryos (Figure 4). Comparison of differentiation rates showed that green spots started to appear on the surface of both types of callus at 12 to 14 days after transfer to regeneration media (Figure 5). However, the differentiation rates were significantly higher in cultures initiated from germinating embryos of the two landraces tested (48 to $56 \%$ ) compared to those of cultures initiated from soaked embryos ( 24 to $28 \%$ ).

TABLE 1. Effect of explant types on callus induction of two

wheat landraces. Values were means from four replicates $\pm \mathrm{SE}$

\begin{tabular}{|c|c|c|c|c|}
\hline Explant & Landrace & $\begin{array}{c}\text { Days to } \\
\text { callus } \\
\text { induction }\end{array}$ & $\begin{array}{l}\text { Callus induction } \\
\text { frequency }(\%)\end{array}$ & Callus morphology \\
\hline \multirow[t]{2}{*}{ Soaked mature embryo } & Tafila & $3-5$ & $76 \pm 7.4$ & $\begin{array}{c}\text { Compact, smooth, shiny and } \\
\text { globular }\end{array}$ \\
\hline & Ajloun & $3-5$ & $72 \pm 4.8$ & \\
\hline \multirow[t]{2}{*}{ Germinating mature embryo } & Tafila & 1 & 100 & $\begin{array}{l}\text { Compact, smooth, shiny and } \\
\text { globular }\end{array}$ \\
\hline & Ajloun & 1 & $96 \pm 4$ & \\
\hline
\end{tabular}




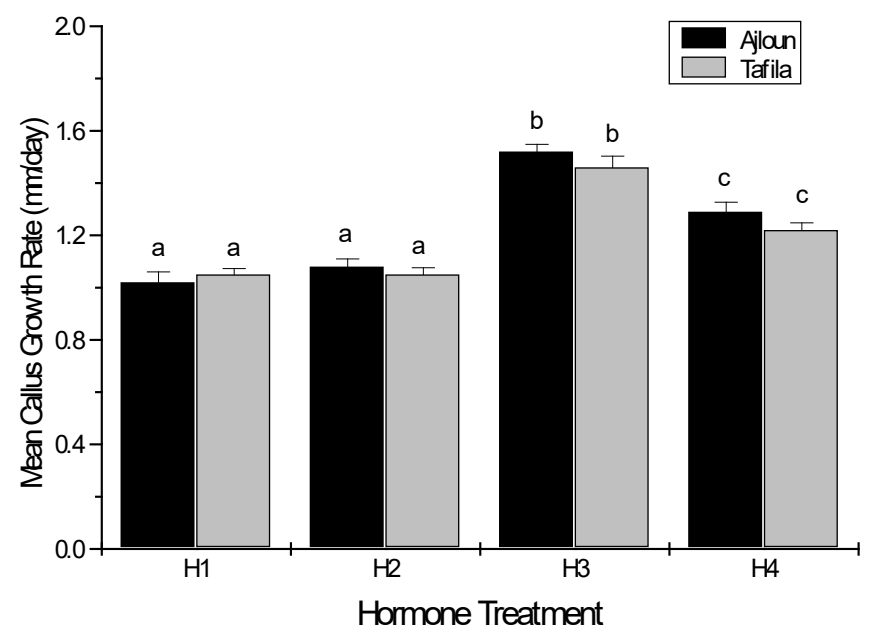

FIGURE 1. Mean growth rate of callus from germinating mature embryos of two wheat landraces cultured at different concentrations of 2,4-D and dicamba. Values presented were means from four replicates \pm SE. Mean values with different letters in a column were significantly different according to Duncan's multiple range test $(\mathrm{p}<0.05)$

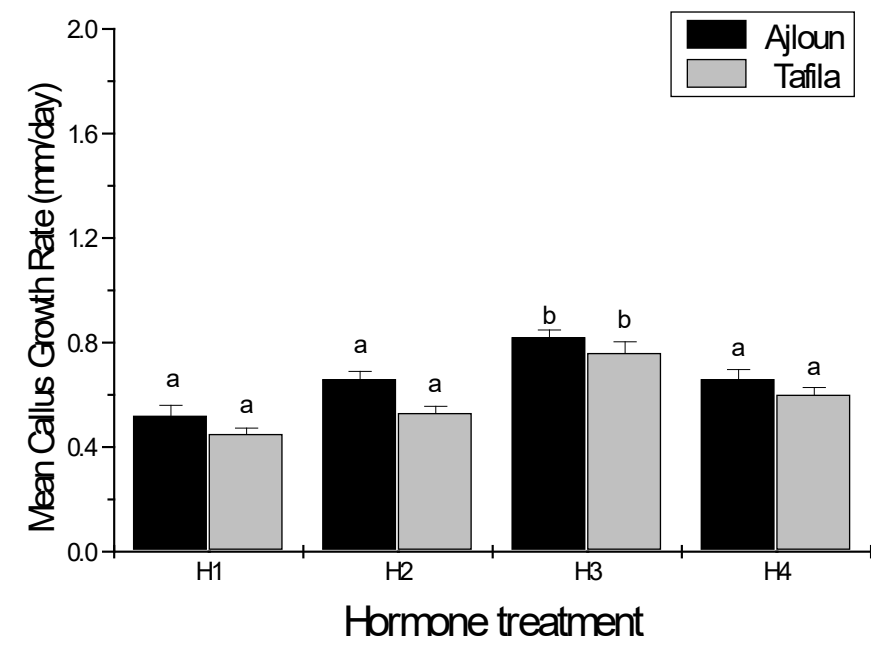

FIGURE 2. Mean growth rate of callus from soaked mature embryos of two local wheat landraces cultured at different of concentrations of 2,4-D and dicamba. Values presented were means from four replicates $\pm \mathrm{SE}$. Mean values with different letters in a column were significantly different according to Duncan's multiple range test $(\mathrm{p}<0.05)$ 


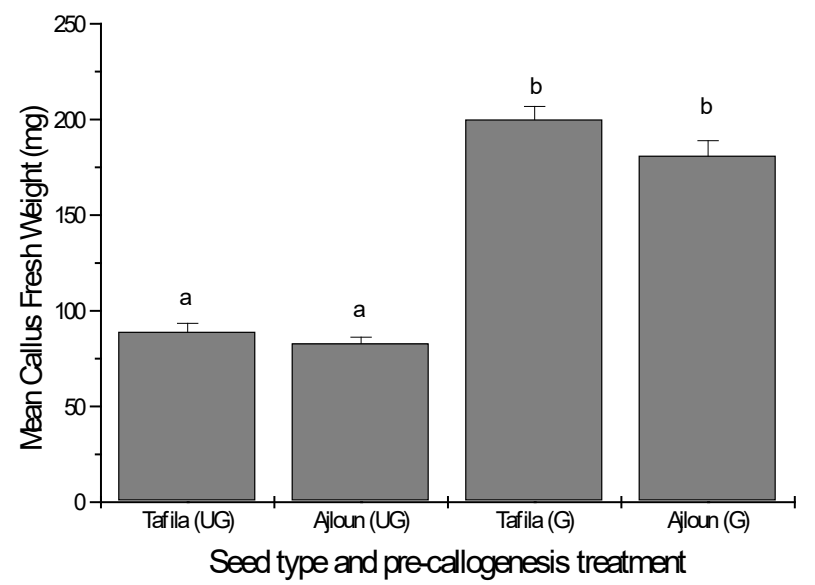

FIGURE 3. Mean fresh weight of callus developed from germinating $(G)$ and soaked (UG) mature wheat embryos scored after 28 days of culture. Values were means from four replicates \pm SE. Mean values with different letters in a column were significantly different according to Duncan's multiple range test $(\mathrm{p}<0.05)$

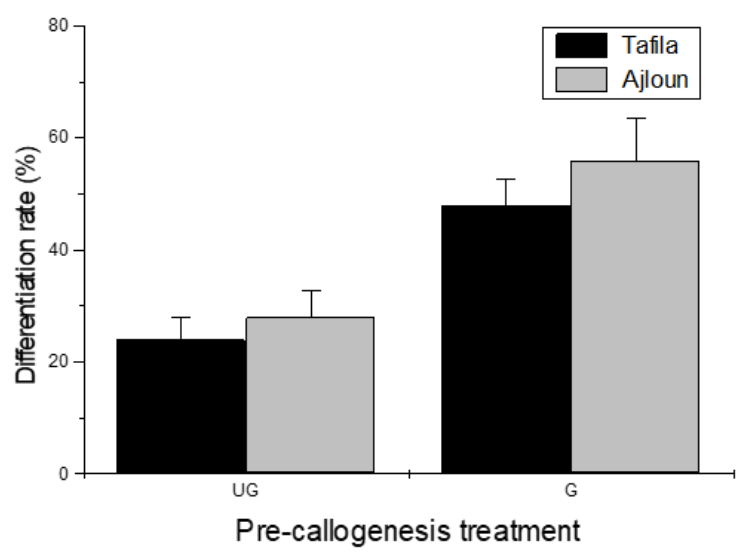

FIGURE 4. The differentiation rates of callus derived from germinating (G) and soaked (UG) mature embryos of two wheat landraces scored after 4 weeks of culture on differentiation media. Values were means from five replicates \pm SE. Mean values with different letters in a column were significantly different according to Duncan's multiple range test $(\mathrm{p}<0.05)$

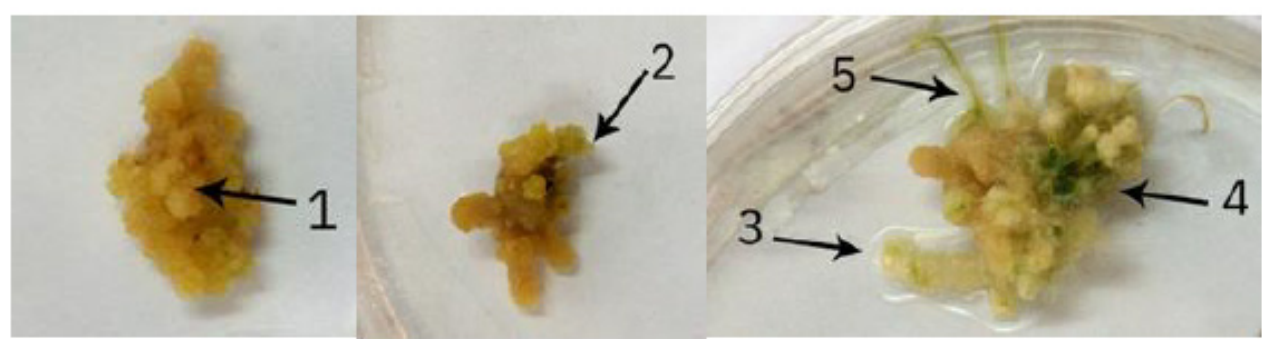

FIGURE 5. Callus induction and differentiation. Callus from germinating (1) and soaked (2) mature embryos of wheat formed 4 weeks after culture on callus induction medium. Development of green spots (3, 4 and 5) on callus derived from germinating embryos at 12-14 days after culture on regeneration media. 
DISCUSSION

In wheat, callus formation, growth and regeneration potential besides genotype and media composition (Mahmood et al. 2012) are also dependent on the explant source (Shah et al. 2003). Therefore, the choice of a favorable explant is inevitable for the success of wheat tissue culture. Although most studies and reviews have shown that immature embryos are the best explants source for wheat tissue culture (Yang et al. 2015), it is usually laborious, time-consuming, season-dependent, and tedious to obtain continuously. Nowadays, explants used for wheat tissue culture are being re-evaluated, and studies are directed towards using mature embryos. The use of mature embryos offers remarkable advantages over immature embryos of ready availability and abundance from dry seeds. However, mature embryos are more recalcitrant to tissue culture than immature embryos. The low callus induction rate due to factors such as explants physiological state and degree of differentiation is considered to be one of the key reasons for the low regeneration potential of recalcitrant cereal cultivars (Abumhadi et al. 2005; Bradley et al. 2001; Jiang et al. 1998), hence, the present work focused on devising an effective protocol for callus induction and growth using germinating mature wheat embryo explants. The results of this study demonstrated strong callusing response of germinating embryos. Cultures of germinated embryos depicted an approximate 20 to $25 \%$ and $100 \%$ increase in the mean callus induction percentages and callus growth rates, respectively, over those of soaked embryos. This result is consistent with the findings of Zhao et al. (2010) which showed a significant improvement of callus culture using germinating sweet sorghum embryos.

The high callogenesis response observed in this study may have been due to the differences in the physiological status of germinating mature embryos and its soaked counterpart. It is possible that steps activated in germinating embryos including cell division and cell proliferation (Fernandez et al. 1999; Ortiz et al. 1996; Ozias-Akin \& Vasil 1982) in addition to activation of metabolic processes causing the raise of endogenous levels of hormones and storage products (de Almeida et al. 2012; Elmeer 2013; Gliwicka et al. 2012; Phillips 2004; Yaseen et al. 2013) may have positively influenced the vitality status of mature embryos and consequently improved its totipotency potential.

Higher efficiency of green spot development on callus derived from germinated embryos compared to those derived from soaked embryos was also demonstrated in this study. Since a strong positive correlation is reported to exist between the development of green spots and regeneration potential in cereal callus cultures (Ben Amer et al. 1992; Nabors et al. 1982), callus of germinated embryos can be very useful for efficient plantlet regeneration and genetic transformation of wheat cultivars.

\section{CONCLUSION}

In this study an efficient callus induction and differentiation protocol for wheat (Triticum aestivum) from germinating mature embryos has been established. This protocol has been proven to be superior to those using soaked embryos, and it may have valuable application for the in vitro selection and transgenesis of wheat.

\section{REFERENCES}

Abumhadi, N., Kamenarova, K., Todorovska, E., Dimov, G., Trifonova, A., Gecheff, K. \& Atanassov, A. 2005. Callus induction and plant regeneration from barley mature embryos (Hordem vulgare L.). Biotechnology and Biotechnological Equipment 19(3): 32-38.

Battal, A. 2010. Optimization of mature embryo based regeneration and genetic transformation of Turkish wheat cultivars. Msc Thesis. Middle East Technical University (Unpublished).

Ben Amer, I., Worland, A. \& Borner, A. 1992. In vitro culture variation of wheat caused by genes affecting plant growth habit in vivo. Euphytica 61(3): 233-240.

Bradley, D., Bruneau, A. \& Qu, R. 2001. Effect of cultivar, explants treatment and medium supplements on callus induction and plantlet regeneration in perennial ryegrass. International Turfgrass Society Research Journal 9: 152-156.

Chugh, A. \& Khurana, P. 2003. Regeneration via somatic embryogenesis from leaf basal segments and genetic transformation of bread and emmer wheat by particle bombardment. Plant Cell, Tissue and Organ Culture 74(2): 151-161.

Compton, M.E. 1994. Statistical methods suitable for the analysis of plant tissue culture data. Plant Cell, Tissue and Organ Culture 37(3): 217-242.

Coskun, Y., Duran, R.E., Savaskan, C., Demirci, T. \& Hakan, M.T. 2013. Efficient plant regeneration with arabinogalactanproteins on various ploidy levels of cereals. Journal of Integrative Agriculture 12(3): 420-425.

de Almeida, M., de Almeida, C.V., Graner, E.M., Brondani, G.E. \& de AbreuTarazi, M.F. 2012. Pre-procambial cells are niches for pluripotent and totipotent stem-like cells for organogenesis and somatic embryogenesis in the peach palm: A histological study. Plant Cell Reports 31(8): 14951515.

Ding, L., Li, S., Gao, J., Wang, Y., Yang, G. \& He, G. 2009. Optimization of agrobacterium-mediated transformation conditions in mature embryos of elite wheat. Molecular Biology Reports 36(1): 29-36.

Elmeer, K.E.S. 2013. Factors regulating somatic embryogenesis in plants. In Somatic Embryogenesis and Gene Expression, edited by Aslam, J., Srivastava, P.S. \& Sharma, M.P. New Delhi, India: Narosa Publishing House. pp. 56-81. 
Fernandez, S., Michaux-Ferriere, N. \& Coumans, M. 1999. The embryogenic response of immature embryo cultures of durum wheat (Triticum durum Desf.): Histology and improvement by $\mathrm{AgNO}_{3}$. Plant Growth Regulation 28(3): 147-155.

Gliwicka, M., Nowak, K., Ciesla, E. \& Gaj, M. 2012. Expression of seed storage product genes (CRA1 and OLEO4) in embryogenic cultures of somatic tissues of Arabidopsis. Plant Cell, Tissue and Organ Culture (PCTOC) 109(2): 235-245.

Jiang, W., Cho, M.J. \& Lemaux, P.G. 1998. Improved callus quality and prolonged regenerability in model and recalcitrant barley (Hordeum vulgare L.) cultivars. Plant Biotechnology 15(2): 63-69.

Kumar, R., Mamrutha, H.M., Kaur, A., Venkatesh, K., Grewal, A., Kumar, A. \& Tiwari, V. 2017. Development of an efficient and reproducible regeneration system in wheat (Triticum aestivum L.). Physiology and Molecular Biology of Plants 23(4): 945-954.

Mahmood, I., Abdul, R., Khan, Z., Hafiz, I. \& Kaleem, S. 2012. Evaluation of tissue culture responses of promising wheat (Triticum aestivum L.) cultivars and development of efficient regeneration system. Pakistan Journal of Botany 44(1): 277-284.

Mendoza, M.G. \& Kaeppler, H.F. 2002. Auxin and sugar effects on callus induction and plant regeneration frequencies from mature embryo of wheat (Triticum aestivum L.). In Vitro Cellular and Developmental Biology-Plant 38(1): 39-45.

Miroshnichenko, D.N., Filippov, M.V. \& Dolgov, S.V. 2013. Medium optimization for efficient somatic embryogenesis and in vitro plant regeneration of spring common wheat varieties. Russian Agricultural Sciences 39(1): 24-28.

Miroshnichenko, D., Poroshin, G. \& Dolgov, S. 2011. Genetic transformation of wheat using mature seed tissues. Applied Biochemistry and Microbiology 47(8): 767-775.

Miroshnichenko, D., Filippov, M. \& Dolgov, S. 2009. Effects of daminozide on somatic embryogenesis from immature and mature embryos of wheat. Australian Journal of Crop Science 3(2): 83-94.

Moghaieb, R.E., El-Arabi, N.I., Momtaz, O.A., Youssef, S.S. \& Soliman, M.H. 2010. Genetic transformation of mature embryos of bread (T. aestivum) and pasta (T. durum) wheat genotypes. Genetically Modified Crops 1(2): 87-93.

Murashige, T. \& Skoog, F. 1962. A revised medium for rapid growth and bioassays with tobacco cell cultures. Physiologia Plantarum 15(3): 473-497.

Murín, R., Mészáros, K., Nemecek, P., Kuna, R. \& Faragó, J. 2012. Regeneration of immature and mature embryos from diverse sets of wheat genotypes using media containing different auxins. Acta Agronomica Hungarica 60(2): 97-108.

Nabors, M., Kroskey, C. \& McHugh, D. 1982. Green spots are predictors of high callus growth rates and shoot formation in normal and in salt stressed tissue cultures of oat (Avena sativa L.). Zeitschrift für Pflanzenphysiologie 105(4): 341-349.

Ortiz, J.P.A., Fama, G., Vallejos, R.H. \& de Halac, I.N. 1996. Cytodifferentiation and cell organization in the somatic embryogenesis of wheat (Triticum aestivum L). Biocell 20(1): 61-66.
Ozbay, A. \& Özgen, M. 2010. Is heterosis noticeable in the callus response of winter durum wheat F1 hybrids? Biologia Plantarum 54(4): 769-772.

Ozias-Akin, P. \& Vasil, K. 1982. Plant regeneration from cultured immature embryos and inflorescences of Triticum aestivum $\mathrm{L}$. (wheat): Evidence for somatic embryogenesis. Protoplasma 110(1982): 95-105.

Parmar, S., Sainger, M., Chaudhary, D. \& Jaiwal, P. 2012. Plant regeneration from mature embryo of commercial Indian bread wheat (Triticum aestivum L.) cultivars. Physiology and Molecular Biology of Plants 18(2): 177-183.

Patnaik, D., Vishnudasan, D. \& Khurana, P. 2006. Agrobacteriummediated transformation of mature embryos of Triticum aestivum and Triticum durum. Current Science 91(3): 307317.

Phillips, G.C. 2004. In vitro morphogenesis in plants-recent advances. In Vitro Cellular and Developmental Biology-Plant 40(4): $342-345$

Rashid, U., Ali, S., Ali, G.M., Ayub, N. \& Masood, M.S. 2009. Establishment of an efficient callus induction and plan regeneration system in Pakistani wheat (Triticum aestivum) cultivars. Electronic Journal of Biotechnology 12(3): 4-5.

Rajjou, L., Duval, M., Gallardo, K., Catusse, J., Bally, J., Job, C. $\&$ Job, D. 2012. Seed germination and vigor. Annual Review of Plant Biology 63: 507-533.

Repellin, A., Baga, M., Jauhar, P. \& Chibbar, R. 2001. Genetic enrichment of cereal crops via alien gene transfer: new challenges. Inorganic nutrient manipulation in the induction of embryogenic callus from immature embryos of wheat Plant Cell Tissue and Organ Culture 64(2-3): 159-183.

Ren, J., Wang, X. \& Yin, J. 2010. Dicamba and sugar effects on callus induction and plant regeneration from mature embryo culture of wheat. Agricultural Sciences in China 9(1): 31-37.

Shah, M., Jabeen, M. \& Ilahi, I. 2003. In vitro callus induction, its proliferation and regeneration in seed explants of wheat (Triticum aestivum L.) Var.LU-26S. Pakistan Journal of Botany 35(2): 209-217.

Tang, Z., Ren, Z., Wu, F., Fu, S., Wang, X. \& Zhang, H. 2006. The selection of transgenic recipients from new elite wheat cultivars and study on its plant regeneration system. Agricultural Sciences in China 5(6): 417-424.

Yang, S., Xu, K., Wang, Y., Bu, B., Huang, W., Sun, F., Liu, S \& Xi, Y. 2015. Analysis of biochemical and physiological changes in wheat tissue culture using different germplasms and explant types. Acta Physiologiae Plantarum 37: 120.

Yaseen, M., Ahmad, T., Sablok, G., Standardi, A. \& Hafiz, I.A. 2013. Review: Role of carbon sources for in vitro plant growth and development. Molecular Biology Reports 40(4): 2837-2849.

Yin, G., Wang, Y., She, M., Du, L., Xu, H., Ma, J. \& Ye, X. 2011 Establishment of a highly efficient regeneration system for the mature embryo culture of wheat. Agricultural Sciences in China 10(1): 9-17.

Yu, Y., Wang, J., Zhu, M.L. \& Wei, Z.M. 2008. Optimization of mature embryo-based high frequency callus induction and plant regeneration from elite wheat cultivars grown in China. Plant Breeding 127(3): 249-255. 
Zale, J.M., Borchardt-Wier, H., Kidwal, K.K. \& Stebar, C.M. 2004. Callus induction and plant regeneration from mature embryos of a diverse set of wheat genotypes. Plant Cell Tissue and Organ Culture 76(3): 277-281.

Zhao, L., Liu, S. \& Song, S. 2010. Optimization of callus induction and plant regeneration from germinating seeds of sweet sorghum (Sorghum Bicolor Moench). African Journal of Biotechnology 9(16): 2367-2374.
Department of Biological Sciences

The University of Jordan

Amman 11942

Jordan

*Corresponding author; email: tamimi@ju.edu.jo

Received: 20 February 2020

Accepted: 19 September 2020 